\title{
WSPARCIE JAKO NIEZBĘDNY CZYNNIK W PROCESIE POMAGANIA JEDNOSTKOM W KRYZYSIE
}

\begin{abstract}
Support as an essential factor in helping individuals in crisis

A family is an important link of the whole society. Its existence ensures the continuity of the social system. Properly functioning family is a guarantee of conditions for proper child development. The problem appears at the time of occur care and upbringing difficulties that family cannot manage with. In the past it was thought that the best kind of help for child is excluding from the problematic environment. This trend is currently being reversed. Both state policy as well as local community are the foundations for helping families in crisis. Various legislative solutions are implemented to protect the biological family. Social support activates aid mechanisms which are important to cope with difficulties. The aim of the article is, therefore, to show the links between the state's social policy and social support. The complementarity of these services provides effective help, and thus prevents placing children in foster care.
\end{abstract}

Key words: family, social support, social policy

Bez wątpienia otoczeniem, które najlepiej oddziałuje na jednostkę i jej rozwój, jest prawidłowo funkcjonująca rodzina. Oczywiście nikt lepiej nie rozumie potrzeb dziecka niż jego rodzice. To właśnie oni potrafią stworzyć warunki, które będą sprzyjały harmonijnemu rozwojowi. Młody człowiek powinien być wychowywany w atmosferze szacunku, miłości, bezpieczeństwa, a także w poczuciu, że każdy członek rodziny jest ważny i jego potrzeby są dostrzegane oraz zaspokajane w miarę możliwości. Rodzina jest pierwszym, a zarazem podstawowym środowiskiem wychowawczym, w którym osoba po raz pierwszy spotyka się z wartościami, rolami i postawami. To członkowie rodziny pokazują, jak zachowywać się na forum, jak odnaleźć się w zastanej rzeczywistości (Wosik-Kawala 2012: 9-12). W sytuacji gdy to rodzina nie wypełnia podstawowych zadań, mówi się o rodzinie niewydolnej wychowawczo, w której na pierwszy plan wysuwają się zaburzenia w prawidłowym funkcjonowaniu, znacznie odbiegające od normy. Zdarza się, że są to rodziny niekompletne lub rozbite, co jest powodem trudności we współżyciu i niezabezpieczenia podstawowych potrzeb każdego z członków. Natomiast rodzina, 
w której dominują zachowania niezgodne z prawem, szerzą się wszelkie uzależnienia, kradzieże i pojawiają się inne trudności, to rodzina patologiczna. W obu wyżej wymienionych przypadkach sytuacja panująca w domu nie sprzyja rozwojowi dziecka. Niejednokrotnie rodzice nie interesują się młodym pokoleniem z uwagi na trudności, które sami przeżywają i nie potrafią sobie z nimi poradzić (Piech 2012: 16-17). Polityka społeczna państwa opiera się na założeniach, że źle funkcjonująca rodzina negatywnie oddziałuje na dziecko, stąd też pojawiają się problemy szkolne, problemy z zachowaniem itp. Najczęściej to właśnie w środowisku szkolnym są zauważane trudności dzieci, przez co automatycznie uruchamia się wiele działań mających na celu pomoc dziecku. Chcąc rozwiązać problemy dziecka, należy pomóc całej rodzinie, tym samym należy odwrócić dotychczasową tendencję, która koncentrowała pomoc rodzinie tylko na dziecku (Stelmaszczuk 1999: 163).

Co więcej, rodzina jest naturalnym i niezastąpionym środowiskiem wychowawczym, dlatego też wszystkie działania podejmowane przez państwo mają na celu ochronę rodziny przez wprowadzanie odpowiednich ustaw i rozwiązań prawnych. Człowiek jest jednostką społeczną, co warunkuje jego funkcjonowanie w szerszym otoczeniu (Bakiera 2006). Jednocześnie potrafi uruchomić mechanizmy, dzięki którym angażuje się w udzielanie pomocy osobom znajdującym się w kryzysie. Tak więc i organy państwowe, i społeczeństwo są wsparciem dla osób przeżywających trudności.

\section{Kryzysy rodziny i wsparcie społeczne}

Każda osoba, niezależnie od wykształcenia, statusu materialnego czy wieku, przechodziła kryzys, lecz to jego rozstrzygnięcie decyduje o sile wewnętrznej danej osoby. Jest wiele rodzin, które samodzielnie potrafią przezwyciężyć trudności, jeśli jednak rodzina ma problemy z uporaniem się z zaistniałymi sytuacjami, może liczyć na pomoc czy to ze strony rodziny, środowiska lokalnego, czy też instytucji specjalnie do tego powołanych (Dąbrowska 2015), ponieważ „rodzina jest swoistą emanacją społeczeństwa, nie tylko istnieje w społeczeństwie, ale społeczeństwo na swój sposób jest obecne w niej" (Biernat 2014: 186).

Obecnie obserwuje się dewaluację wartości rodzinnych. Indywidualizm jednostek i szeroko pojęta autonomia przyczyniają się do fragmentaryzacji więzi. W konsekwencji prowadzi to do obniżenia roli samopomocy wewnętrznej. Doceniona zostaje pomoc zewnętrzna, czyli instytucje i sieci wsparcia społecznego (Przeperski 2017). W socjologii zwraca się uwagę na istotną rolę rodziny w społeczeństwie, należy mieć również na względzie to, że społeczeństwo także odgrywa znaczą rolę w rodzinach. Zjawisko to jest szczególnie widoczne przy tworzeniu sieci wsparcia. Andrzej Janke uważa nawet, że „W układzie społecznym obowiązuje zasada naczyń połączonych, co oznacza potrzebę liczenia się z relacją jednostka-rodzina-społeczeństwo" (Przeperski 2017: 138). 
Takie holistyczne ujęcie pozwala na skuteczną pomoc, angażuje się bowiem wszystkie możliwe zasoby.

Najczęściej odbiorcami takiej pomocy są osoby permanentnie korzystające z usług pomocy społecznej. Niejednokrotnie ich trudności wynikają ze zjawiska wyuczonej bezradności, które jest szczególnie niepokojące $\mathrm{z}$ uwagi na to, że jego przedstawicielami są osoby coraz młodsze. Zgodnie z założeniami klasycznej teorii wyuczonej bezradności Martina Seligmana „jest to zjawisko o charakterze poznawczym, gdyż jego geneza jest związana z oczekiwaniami jednostki dotyczącymi antycypowanych niepowodzeń przyszłych działań" (Przewłocka 2014: 194). Mechanizmem, który odpowiada za ten syndrom, jest wytworzenie przekonania o braku wpływu na wydarzenia. Pojawia się przeświadczenie o braku mocy sprawczej, w konsekwencji rodziny przestają się starać i walczyć o lepszy byt. W takiej rodzinie najbardziej cierpią dzieci, rodzice ulegają bowiem kryzysom, a wtedy rodzina przestaje prawidłowo funkcjonować.

Skoro społeczeństwo nie istnieje bez rodzin, a rodziny nie mogą być wyrwane ze społeczeństwa, to w obliczu napotkanych trudności ludzie mogą liczyć na pomoc zarówno najbliższych, jak i środowiska lokalnego, które tworzy tak zwaną sieć wsparcia. To za jej przyczyną można przezwyciężyć krytyczne momenty, a także odwrócić proces pauperyzacji czy wykluczenia społecznego. Sieć wsparcia tworzą grupy nieformalne i struktury sformalizowane, czyli organizacje społeczne lub lokalne instytucje (Gagacka 2011). Istnieje wiele modeli wsparcia społecznego, które są niezbędne przy organizacji działań pomocowych. Tworzą one swego rodzaju bazę metodyczną i teoretyczną służącą do podejmowania skutecznej pomocy przy wykorzystaniu zasobów drzemiących w społeczeństwie (Dąbrowska 2015).

Zdaniem Heleny Radlińskiej zasoby środowiska to wszystkie potencjały, takie jak siły społeczne, duchowe i fizyczne, które ulegają przekształceniom, aby być wykorzystane $\mathrm{w}$ procesie modernizacji, regeneracji i aktywizacji środowiska. W odniesieniu do kryterium rzeczowego autorka wyróżnia fizjograficzne cechy środowiska, poziom urbanizacji, organizacje edukacyjne, sieć pomocy społecznej i instytucje odnoszące się bezpośrednio do życia kulturalnego. Stosując kryterium relacyjne, mówi się o członkach społeczności w kręgach sąsiedzkich, o stowarzyszeniach i instytucjach. Elementy te są wykorzystywane do wspólnych przedsięwzięć, a także jako sieć wsparcia w sytuacjach kryzysowych. Kryterium tożsamościowe zaznacza zasoby kulturowe, które są istotne w tworzeniu tożsamości, poczuciu przynależności i tradycji. Co więcej, kształtują osobiste wzory zachowań w relacjach interpersonalnych (Gagacka 2011). W innej publikacji wskazuje się dwa wymiary wsparcia społecznego. Pierwszy z nich - strukturalny - opiera się na faktycznie istniejącej i dostępnej sieci społecznej, która wyróżnia się na tle innych faktem przynależności, założeniem tworzenia i utrzymywania więzi, a także istnienia kontaktów społecznych. Tym samym pełni funkcję pomocową w stosunku do osób przeżywających kryzys (Sęk, Cieślak 2004). Drugi wymiar określa się mianem wsparcia funkcjonalnego. Termin ten jest definiowany jako rodzaj interakcji międzyludzkiej, której inicjatorem może być jeden lub dwoje uczestników w obliczu trudności, sytuacji krytycznej lub problemowej (Sęk 2007). Niezależnie od wybranego podziału 
na pierwszy plan wysuwa się pomoc oferowana jednostce. Jest to wspólny pierwiastek dla wszystkich form wsparcia.

Instytucje pomocowe powinny być jedynie fundamentem formalnym oferowanej pomocy. Deprecjacja wartości rodzinnych jest predyktorem sytuacji, w której to instytucja dominuje nad systemem rodzinnym. Sytuacja taka nie jest właściwa ani dla dziecka, ani dla osób będących w kryzysie. Dobrą praktyką jest więc budowanie takiego środowiska lokalnego, w którym jednostka ma świadomość przynależności do sieci społecznej, zapewnione jest poczucie bycia kochanym i docenianym (Zamkowska 2009). Wtedy też można liczyć na czyjąś pomoc, zanim skorzysta się z instytucji specjalnie do tego powołanych. Dlatego tak ważne jest wsparcie społeczne, aby kryzysu nie traktować jako rozpadu, ale jako pobudkę do zmiany i wytworzenia nowych wzorów zachowań (Bakiera 2006). Spójne społeczeństwo tworzy wspólnotę, dzięki której można pokonać trudności, kryzysy i konflikty, których przezwyciężenie nie byłoby możliwe, polegając tylko na aktywności indywidualnej (Golinowska 2011). W modelu wsparcia społecznego istotną funkcję, poza rodziną i środowiskiem lokalnym, pełnią systemy komplementarne, takie jak formalny system pomocy społecznej oraz oficjalne systemy pomocy edukacyjnej, medycznej czy ekonomicznej (Kondracka-Szala 2015).

\section{Polityka społeczna państwa wobec problemów jednostki}

Państwo nie chce dopuścić do sytuacji odebrania dzieci z domu rodzinnego, wręcz przeciwnie - skupia się na pomocy dziecku przez pryzmat jego rodziny. Liczba dzieci umieszczonych w pieczy zastępczej w 2018 roku wynosiła 72339 (Informacja Rady Ministrów o realizacji w roku 2018 Ustawy z dnia 9 czerwca 2011 roku o wspieraniu rodziny i systemie pieczy zastępczej: 8). Najczęstszą przyczyną umieszczania dzieci w pieczy zastępczej jest choroba alkoholowa lub niezaradność w sprawach opiekuńczo-wychowawczych. Obie wyżej wymienione sytuacje są możliwe do rozwiązania w taki sposób, aby dziecko pozostało $\mathrm{w}$ rodzinie biologicznej. Priorytetem jest środowiskowa pomoc rodzinie w jej problemach, a tym samym pomoc dziecku. Rodzina jako podstawowa komórka społeczna jest zatem objęta ochroną i wsparciem, aby mogła w pełni realizować swoje obowiązki (www1). Dużym problemem jest szeroko pojęta i potocznie rozumiana „bieda", która jest przyczyną trudności, a jej chroniczne trwanie prowadzi do umieszczenia dzieci w pieczy zastępczej. Owa „bieda to skomplikowana sytuacja społeczno-bytowa rodzin manifestująca się nie tylko brakiem pieniędzy, ale również pewnym? «stylem» życia rodziców, na który składają się strategie radzenia sobie z trudnościami, określony stosunek do świata i ludzi, a w konsekwencji także sposób traktowania własnych dzieci" (Szymańczak 2016: 1). Ludzie tacy są zazwyczaj ubodzy, nie posiadają wykształcenia czy też kwalifikacji, nie pracują i nawet nie zależy im na znalezieniu zatrudnienia. Żyją z dnia na dzień, bez perspektyw. Niejednokrotnie są skonfliktowani z rodzinami. Nie prezentują odpowiednich wzorców wychowawczych, więc nie można mówić o procesie 
wychowania. Taki styl życia uniemożliwia prawidłowe funkcjonowanie rodziny (Szymańczak 2016). Sytuacja ta tworzy inne niebezpieczeństwo, którym jest wykluczenie społeczne. Narodowa Strategia Integracji Społecznej definiuje to zjawisko jako

niepodejmowanie zwyczajowej i społecznie akceptowanej drogi życiowej lub wypadanie z niej. Dotyczy osób żyjących w ubóstwie materialnym, które zostały dotknięte niekorzystnymi procesami społecznymi oraz nie zostały wyposażone w kapitał życiowy umożliwiający im między innymi: normalną pozycję społeczną, odpowiedni poziom kwalifikacji, wejścia na rynek pracy, założenia rodziny. Doświadczają przejawów dyskryminacji oraz kulturowych uprzedzeń i stereotypów (www2: 20).

Jest to więc nowe wyzwanie dla pracy socjalnej. Pracownik socjalny, chcąc zmobilizować osobę do podjęcia zatrudnienia, korzysta z narzędzia wprowadzonego na mocy ustawy o pomocy społecznej, czyli kontraktu socjalnego. Jest to zobowiązanie beneficjenta do aktywnego poszukiwania zatrudnienia. Osoba podpisująca taki kontrakt może liczyć na dodatkową pomoc finansową, na przykład na zakup biletów przejazdu, niewywiązanie się skutkuje zaś zatrzymaniem świadczeń z pomocy społecznej. Jest to metoda, która bezpośrednio dotyczy dorosłego, ale pośrednio takim narzędziem pomaga się dziecku. Podjęcie pracy to pierwszy krok do zmiany sytuacji życiowej (Kowalczyk 2008).

Konieczność komplementarności wszystkich usług na rzecz osób w kryzysie wymaga od polityki państwowej zmiany w celu wyboru najlepszej drogi pomocy. W związku z licznymi przeobrażeniami i zamianami, jakie zachodzą w rodzinie, należałoby zmienić system pomocowy, który w niewielkim stopniu odpowiada na problemy istniejące w dzisiejszych rodzinach. Należałoby udoskonalić zasady i metody pracy wykorzystywane w pracy socjalnej. Być może polityka społeczna państwa powinna skupić się na prewencji, a nie zwalczaniu konsekwencji, obserwowane sytuacje są bowiem wynikami wcześniejszych wydarzeń (Kawula, Brągiel, Janke 2014). Obecna polityka społeczna państwa jest polityką aktywizującą, czyli fundamentem zmiany ma być odpowiedzialność osobista i wysiłek jednostkowy włożony w przezwyciężenie trudności przy jednoczesnym wsparciu innych podmiotów. W szczególności chodzi o włączenie sieci lokalnych do działań pomocowych (Grewiński, Kamiński 2011). Obecnie odchodzi się od koncepcji opiekuńczej funkcji państwa przy jednoczesnej mobilizacji beneficjentów do podjęcia pracy, tym samym zmniejszając ich udział w korzystaniu z pomocy społecznej. Dąży się więc do aktywizacji społecznej, która jest uzyskiwana na drodze pewnych sankcji społecznych. W tym celu państwo wprowadza nowe ustawy lub aktualizuje już wcześniej wprowadzone (Karwacki, Rymsza 2011). Celem tych jurysdykcji jest zarówno aktywizacja zawodowa osób długotrwale bezrobotnych, jak i wychodzących z nałogów oraz pomoc rodzinom w wypełnianiu funkcji opiekuńczo-wychowawczych. Jak już wyżej wspomniano, należy najpierw pomóc rodzicom uporać się z ich problemami, a dopiero w następnym kroku skupić się na dzieciach. Poniższe ustawy zostały wprowadzone, aby poprawić kondycję polskich rodzin i zniwelować niedoskonałości obecnego sytemu wsparcia. 
Przykładem może być Ustawa z dnia 12 marca 2004 roku o pomocy społecznej, zaktualizowana 5 lipca 2019 roku. W tejże ustawie w art. 11 ust. 2 ustawodawca zwraca uwagę na to, że

brak współdziałania osoby lub rodziny z pracownikiem socjalnym lub asystentem rodziny (...) w rozwiązywaniu trudnej sytuacji życiowej, odmowa zawarcia kontraktu socjalnego, niedotrzymanie jego postanowień, odmowa podjęcia zatrudnienia (...) lub odmowa podjęcia leczenia odwykowego w zakładzie lecznictwa odwykowego przez osobę uzależnioną mogą stanowić podstawę do odmowy przyznania świadczenia, uchylenia decyzji o przyznaniu świadczenia lub wstrzymania świadczeń pieniężnych z pomocy społecznej (Ustawa z dnia 12 marca 2004 o pomocy społecznej: 9).

Takie rozwiązanie jak najbardziej wpisuje się w aktywną politykę państwa. Mobilizuje beneficjentów do podjęcia starań w celu poprawy swojej sytuacji. Rolą asystenta rodziny jest pomoc w rozwiązaniu trudności w środowisku życia dziecka, a zadaniem współpracy jest zapobieganie umieszczaniu dzieci w pieczy zastępczej.

Przywołany asystent rodziny jest kolejnym instrumentem legislacyjnym, którego podstawową rolą jest wspieranie rodziców w prawidłowym sprawowaniu funkcji opiekuńczo-wychowawczych oraz wsparcie w nabywaniu umiejętności radzenia sobie w trudnych sytuacjach (Krasiejko 2016). Profesja ta została powołana na mocy Ustawy z dnia 9 czerwca 2011 roku o wspieraniu rodziny i systemie pieczy zastępczej. W myśl tej ustawy rodzina przeżywająca trudności może liczyć na pomoc „instytucji i podmiotów działających na rzecz dziecka i rodziny; placówek wsparcia dziennego; rodzin wspierających" (Ustawa z dnia 9 czerwca 2011 roku o wspieraniu rodziny i systemie pieczy zastępczej: 5). Zgodnie z założeniami ustawy wszystkie te działania mają być zorganizowane i prowadzone przez samorządy lokalne. Znowu więc można odnaleźć odniesienie do aktywnej polityki, w której to obywatele samodzielnie się wspierają i w najbliższym otoczeniu szukają pomocy. W przytoczonej wyżej sytuacji wysuwa się również inny ważny postulat, mianowicie, że należy najpierw podjąć próbę działań pomocowych w rodzinie, a dopiero brak oczekiwanych rezultatów powinien doprowadzić od odebrania władzy rodzicielskiej. Z tego wynika, że udziela się bezpośredniego wsparcia rodzicom, przez co pośrednio pomaga się dziecku (Przeperski 2017). Również rodzina wspierająca jest nową formą pomocy, która wykorzystując zasoby rodziny i teorię społecznego uczenia się, pokazuje na swoim przykładzie jak prawidłowo postępować z dziećmi, jak rozwiązywać problemy opiekuńczo-wychowawcze i skutecznie wypełniać rolę rodzica (Rodziny wspierajace. Poradnik dla służb społecznych 2017).

Inną metodą opierającą się na wsparciu społecznym jest Konferencja Grupy Rodzinnej, opisana prze Jarosława Przeperskiego. Jest to

innowacyjna metoda wpisująca się w nowe trendy pracy z rodzinami będące reakcją na nieskuteczność dotychczasowych rozwiązań. (...) Są to działania podejmowane przez rodzinę, wspierane przez koordynatora KGR, mające doprowadzić do spotkania jak największej liczby członków rodziny w celu podjęcia próby rozwiązania problemu, jaki się w niej pojawił (Przeperski 2015: 13-15). 
Istotą tej metody jest również pomoc dziecku w wyniku skupienia się się na jego rodzinie. W opinii jednego z badaczy jest to „spotkanie rodziny dalszej, które jest organizowane w następstwie kryzysu, jaki dotknął dziecko będące członkiem szerszej społeczności rodzinnej" (Bad 2005: 389 za: Przeperski 2015: 15). Asystent rodziny, rodziny wspierające i Konferencja Grupy Rodzinnej to formy pomocy skoncentrowane na najbliższym środowisku, właściwie z niewielkim udziałem instytucji formalnych. Rolą asystenta rodziny i koordynatora KGR jest znalezienie w najbliższym otoczeniu osób, które mogłyby udzielić wsparcia i pomocy, aby zapobiec ograniczeniu władzy rodzicielskiej. Jest to przykład uzupełniania się usług, ponieważ asystent rodziny świadczy pomoc instytucjonalną, ale angażuje on osoby z najbliższego otoczenia, które mogą udzielić wsparcia, co jest pomocą nieinstytucjonalną.

Ostatnią ustawą, którą warto przywołać, jest Ustawa z dnia 19 lipca 2019 roku o realizowaniu usług społecznych przez Centrum Usług Społecznych. Przez te usługi rozumie się

działania z zakresu: polityki prorodzinnej, wspierania rodziny, systemu pieczy zastępczej, pomocy społecznej, promocji i ochrony zdrowia, wspierania osób niepełnosprawnych, edukacji publicznej, przeciwdziałania bezrobociu, kultury, kultury fizycznej i turystyki, pobudzania aktywności obywatelskiej, mieszkalnictwa, ochrony środowiska, reintegracji zawodowej i obywatelskiej (Ustawa z dnia 19 lipca 2019 roku o realizowaniu usług społecznych przez Centrum Usług Społecznych: 1).

Zakres działań w ramach tej ustawy wypełnia wszelkie luki systemu opieki społecznej. Są to działania wielotorowe, nieskupiające się na konkretnej grupie społecznej, ale obejmujące swoim zakresem wszystkich mieszkańców na danym terenie. Zadania te również zostały powierzone jednostkom samorządu terytorialnego. To właśnie te jednostki najbardziej znają problemy mieszkańców, a także potrafią rozpoznać i nazwać zasoby oraz potencjał tkwiący w środowisku lokalnym. Ustawa ta opiera się również na reintegracji i aktywności obywatelskiej. Tym samym być może będzie kluczem do rozwiązania problemów społecznych i ostatecznie zakończy erę państwa opiekuńczego na rzecz aktywności obywatelskiej i pracy wszystkich jednostek w celu poprawy jakości życia (Ustawa z dnia 19 lipca 2019 roku o realizowaniu usług społecznych przez Centrum Usług Społecznych).

\section{Podsumowanie}

Wsparcie społeczne to istotny instrument $\mathrm{w}$ rozstrzyganiu kwestii socjalnych, a także ważny element polityki społecznej. Polityka aktywizacyjna, do której obecnie próbuje się przechodzić, zakłada wysiłek jednostki przy jednocześnie otrzymywanym wsparciu. Wszystkie ustawy wprowadzają pewne formalne aspekty, natomiast wsparcie społeczne niejednokrotnie wypełnia te aspekty w praktyce. Uczestnictwo w relacjach społecznych to korzyść zarówno dla rodzin, jak i całego systemu społecznego, który funkcjonuje. 
Niestety, pojawia się zjawisko autonomii rodzinnej, co sprawia, że osoby będące w kryzysie poszukują wsparcia w instytucjach pomocowych lub w środowisku społecznym. Czy ustawy te odniosą pożądany skutek? Czy wsparcie na poziomie społeczeństwa będzie wystarczająco dobre, aby osoby wykształciły pewne umiejętności radzenia sobie z kryzysami? Czy może jednak pomoc Konferencji Grupy Rodzinnej i rodzin wspierających jest niedoceniana? Czy prowadzona polityka społeczna państwa podejmuje wystarczające działania w celu poprawy sytuacji osób żyjących na marginesie? Pytania te pozostają nadal otwarte, ponieważ wsparcie społeczne jest bardzo złożonym aspektem życia, który wymaga ciągłych badań i aktualizacji wiedzy.

\section{Bibliografia}

Bakiera L. (2006). Rodzina z perspektywy socjologicznej i psychologicznej: ciagłość i zmiana. Obrazy życia rodzinnego z perspektywy interdyscyplinarnej. „Rocznik Socjologii Rodziny”, XVII, Wydawnictwo UAM.

Biernat T. (2014). Czy istnieje rodzina ponowoczesna?. „Pedagogia Christiana”, 2 (34): 186.

Dąbrowska A. (2015). Wybrane modele wsparcia społecznego dla rodzin w kryzysie. „Studia nad Rodziną", XIX, 1 (36), Wydawnictwo UKSW.

Gagacka M. (2011). Rola sieci wsparcia w kreowaniu polityki obywatelskiej w skali lokalnej. „Acta Universitatis Lodziensis", Folia Sociologica 38, Wydawnictwo Uniwersytetu Łódzkiego.

Golinowska S. (2011). O spójności i kapitale społecznym oraz europejskiej i polskiej polityce spójności. „Polityka Społeczna”, 5-6.

Grewiński M., Kamiński S. (2011). Sektor gospodarki społecznej w wielosektorowej polityce społecznej - w kierunku usług społecznych, w: M. Grewiński, M. Rymsza (red.), Polityka aktywizacji w Polsce. Usługi reintegracji w sektorze gospodarki spotecznej. Wydawnictwo Wyższej Szkoły Pedagogicznej TWP w Warszawie, Warszawa.

Informacja Rady Ministrów o realizacji w roku 2018 Ustawy z dnia 9 czerwca 2011 roku o wspieraniu rodziny i systemie pieczy zastępczej (Dz.U. z 2019 roku poz. 1111 i 924), Warszawa; https://www.gov.pl/web/rodzina/informacja-rady-ministrow-o-realizacji-w-roku-2018ustawy-z-dnia-9-czerwca-2011-r-o-wspieraniu-rodziny-i-systemie-pieczy-zastepczej-dzu-z-2019-r-poz-1111-i-924 (dostęp: 5.04.2020).

Karwacki A., Rymsza M. (2011). Meandry upowszechniania koncepcji aktywnej polityki spotecznej w Polsce, w: M. Grewiński, M. Rymsza (red.), Polityka aktywizacji w Polsce. Ustugi reintegracji w sektorze gospodarki społecznej. Wydawnictwo Wyższej Szkoły Pedagogicznej TWP w Warszawie, Warszawa.

Kawula S., Brągiel J., Janke A. (2014). Pedagogika rodziny: obszary i panorama problematyki. Wydawnictwo Adam Marszałek, Toruń.

Kondracka-Szala M. (2015). Wsparcie społeczne osób stygmatyzowanych. Wirtualne grupy samopomocowe. Wydawnictwo Difin, Warszawa.

Kowalczyk B. (2008). Ekonomia społeczna w pomocy społecznej w Polsce $w$ walce $z$ wykluczeniem społecznym, w: K. Wódź, S. Pawlas-Czyż (red.), Praca socjalna wobec nowych obszarów 
wykluczenia społecznego. Modele teoretyczne, potrzeby, praktyki. Wydawnictwo Edukacyjne „Akapit”, Toruń.

Krasiejko I. (2016). Asystentura rodziny. Rekomendacje metodyczne i organizacyjne. Wydawnictwo MRPiPS, Warszawa.

Piech A. (2012). Rodzina naturalnym środowiskiem wychowawczym, w: D. Wosik-Kawala (red.), Rodzinne i instytucjonalne środowiska opiekuńczo-wychowawcze. Wydawnictwo UMCS, Lublin. Przeperski J. (2015). Konferencja Grupy Rodzinnej w teorii i praktyce pracy socjalnej z rodzina. Wydawnictwo Edukacyjne „Akapit”, Toruń: 13-15.

Przeperski J. (2017). Przemiany w systemie opieki i wsparcia rodziny z dziećmi. Perspektywa paradygmatu familiocentrycznego. „Pedagogika Społeczna”, XVI, 2 (64): 138.

Przewłocka K. (2014). Zjawisko wyuczonej bezradności u klientów instytucji pomocy społecznejprzyczyny, konsekwencje, możliwości przeciwdziałania, w: M. Piorunek (red.), Pomoc, wsparcie społeczne, poradnictwo. Od teorii do praktyki. Wydawnictwo Adam Marszałek, Toruń: 194.

Rodziny wspierajace. Poradnik dla służb społecznych (2017). Opracowane BPIPS m.st. Warszawy, Warszawa.

Sęk H. (2007). Wprowadzenie do psychologii klinicznej. Wydawnictwo Naukowe „Scholar”, Warszawa.

Sęk H., Cieślak R. (2004). Wsparcie społeczne - sposoby definiowania, rodzaje i źródła wsparcia, wybrane koncepcje teoretyczne, w: H. Sęk, R. Cieślak (red.), Wsparcie społeczne, stres $i$ drowie. Wydawnictwo Naukowe PWN, Warszawa.

Stelmaszczuk Z. (1999). Nowe spojrzenie na rodzinę, w: Z. Stelmaszczuk (red.), Współczesne kierunki w opiece nad dzieckiem. Wybór tekstów. Wydawnictwo Akademickie „Żak”, Warszawa.

Szymańczak J. (2016). Dzieci „odbierane” rodzicom - przyczyny umieszczania dzieci w pieczy zastępczej. „Analizy” 5 (141), Warszawa: 1.

Ustawa z dnia 12 marca 2004 roku o pomocy społecznej (Dz.U. z 2004 roku poz. 1507 z późn. zm.).

Ustawa z dnia 9 czerwca 2011 roku o wspieraniu rodziny i systemie pieczy zastępczej (Dz.U. z 2011 roku poz. 887 z późn. zm.).

Ustawa z dnia 19 lipca 2019 roku o realizowaniu usług społecznych przez Centrum Usług Społecznych (Dz.U. z 2019 roku poz. 1818).

Wosik-Kawala D. (2012). Wstęp, w: D. Wosik-Kawala (red.), Rodzinne i instytucjonalne środowiska opiekuńczo-wychowawcze. Wydawnictwo Uniwersytetu Marii Curie-Skłodowskiej, Lublin. (www1). http://www.gov.pl/web/rodzina/system-opieki-zastepczej-nad-dzieckiem-w-polsce (dostęp: 11.04.2020).

(www2). https://www.ipiss.com.pl/wp-content/uploads/downloads/2012/08/nsis_2000.pdf (dostęp: 4.04.2020).

Zamkowska A. (2009). Wsparcie edukacyjne uczniów z upośledzeniem umysłowym w stopniu lekkim $w$ różnych formach kształcenia na I etapie edukacji. Wydawnictwo Politechniki Radomskiej, Radom. 
